\title{
PREVALENCE AND BIOFILM FORMING ABILITY OF LISTERIA MONOCYTOGENES ISOLATED FROM MEAT
}

\author{
Anna Zadernowska, ${ }^{1}$ Wioleta Chajęcka-Wierzchowska, ${ }^{2}$ Arkadiusz Zakrzewski ${ }^{3}$
}

\begin{abstract}
Listeria monocytogenes is a Gram-positive intracellular bacterium, which causes foodborne listeriosis. This organism can be introduced through many routes to food-processing environments and may become established on foodprocessing equipment. Examination of 130 meat samples was conducted and the Listeria monocytogenes prevalence was determined by using an ISO culture method and PCR method. The isolated strains' ability to form a biofilm was determined with the microplate (MP) method. Out of 130 meat samples examined, $22(17 \%)$ contained L. monocytogenes. The majority $(\mathrm{n}=13 ; 59 \%)$ of the strains were characterized by a no biofilm producer. Four of the of Listeria monocytogenes strains $(18,2 \%)$ showed strong and five of them $(22,7 \%)$ moderate ability to form biofilm
\end{abstract}

UDC Classification: 614; DOI: http://dx.doi.org/10.12955/cbup.v5.1078

Keywords: Listeria monocytogenes, meat, biofilm

\section{Introduction}

Listeria monocytogenes is a Gram-positive, psychotropic foodborne pathogen. The aim of this study was to investigate the incidence of Listeria monocytogenes in raw meat. Moreover, the aim of the study was to determine the isolated strains' ability to form biofilm.

\section{Literature review}

Listeria monocytogenes is able to grow at different temperature (including refrigeration temperature) ranging from 2 to $52{ }^{\circ} \mathrm{C}$, and in food having low $\mathrm{pH}$ value $(4,4)$ or high salt concentration $(14 \%)$. The minimum water activity $\left(\mathrm{a}_{\mathrm{w}}\right)$ for the growth of $L$. monocytogenes in food is 0.92 . The bacteria grow better (short generation and lag time) at the alkaline $\mathrm{pH}$ and high $\mathrm{a}_{\mathrm{w}}$. Listeria monocytogenes grows well in the presence or absence of oxygen. High concentrations of carbon dioxide are necessary to inhibit growth. At least 13 different serotypes of L. monocytogenes are known. Most cases are caused by serotypes $1 / 2 \mathrm{a}, 1 / 2 \mathrm{~b}$ and $4 \mathrm{~b}$. The majority of reported foodborne outbreaks have been caused by serotype 4b (Ryser and Marth, 2007; Kramarenko et al., 2013). The minimum infective dose of L. monocytogenes is unknown, but is believed to vary in accordance with the immunity of the infected individual and the strain type (Bailey et al., 1989). Listeriosis arises from food contamination with Listeria monocytogenes causing encephalitis, septicaemia and miscarriage. The first epidemiologically confirmed foodborne outbreak of listeriosis occurred in 1981 in Canada and was linked to the consumption of Coleslaw salad. Other outbreaks of human listeriosis have been associated with milk, soft cheese, pate, jellied pork tongue, rillettes and other foods of animal or vegetable origin (Capita et al. 2001). Some $L$. monocytogenes strains attach to environmental surfaces and form biofilms, perhaps by using peritrichous flagella encoded by flaA gene. Microorganisms growing in biofilms are protected against cleaning and disinfection and are difficult to eradicate. L. monocytogenes can attach and grow on abiotic surfaces including all types of foods processing surface such as glass, stainless steel, polypropylene, and rubber after contact times as short as 20 minutes. The biofilm formation renders the organisms more resistant to harsh environmental conditions, such as food processing, antibiotics, and detergents (Fux et al.2005; Mafu et al., 1990).

\section{Materials and Methods}

\section{Isolation of Listeria strains}

A total of 130 samples were obtained from several local markets in Olsztyn, north-west Poland. Samples consisted of poultry meat: duck, chicken, turkey $(n=40)$, beef meat $(n=45)$, and pork meat $(n=45)$. All the samples were kept at $4{ }^{\circ} \mathrm{C}$ during transport and during storage before analysis. The analysis was done within 4 hours of purchase.

\footnotetext{
${ }^{1}$ Industrial and Food Microbiology Department, Unversity of Warmia and Mazury in Olsztyn, anna.zadernowska@uwm.edu.pl

${ }^{2}$ Industrial and Food Microbiology Department, Unversity of Warmia and Mazury in Olsztyn, wioleta.chajecka@uwm.edu.pl

${ }^{3}$ Industrial and Food Microbiology Department, Unversity of Warmia and Mazury in Olsztyn, arkadiusz.zakrzewski@ @uwm.edu.pl
} 
Culture method of Listeria monocytogenes isolation was based on the International Standard ISO 112901:1996. For primary enrichment, $25 \mathrm{~g}$ of each of the collected food samples was transferred to $225 \mathrm{ml}$ of Half-Fraser broth (Merck, Poland), homogenized using a stomacher, next incubated overnight at $37^{\circ} \mathrm{C}$. After $24 \mathrm{~h}$ incubation of the primary enrichment broth, $1 \mathrm{ml}$ of the culture obtained was transferred to $10 \mathrm{ml}$ of secondary enrichment broth, the Fraser broth (Merck, Poland). Inoculated Fraser broth was incubated for $48 \mathrm{~h}$ at $37^{\circ} \mathrm{C}$. After incubation, a portion of the culture was taken with a loop for inoculating of the surface of Oxford and Ottawiani and Agosti agars (Merck, Poland). After incubation for $48 \mathrm{~h}$ at $37^{\circ} \mathrm{C}$ the plates were examined for the presence of colonies presumed to be Listeria spp. Colonies suspected to be Listeria spp. were selected for further confirmatory tests indicated in ISO 11290-1:1996. Finally, the colonies identified as L. monocytogenes were confirmed by PCR. Prior to analysis, isolates were stored in a Microbank at $-80^{\circ} \mathrm{C}$ (Biocorp, Poland).

PCR identification of Listeria monocytogenes

Identification using a Multiplex PCR was performed with primers and conditions described previously (Szymczak et al.,, 2011), specific for the Listeria sp. and Listeria monocytogenes based on the amplification of fragments of 16S rRNA gene sequence (938 bp) and iap (287 bp) (Table 1). In all PCR reactions used, amplified products were analyzed by electrophoresis through a 1,5\% high resolution agarose gel (Promega) in $1 \mathrm{x}$ TBE buffer $\mathrm{pH} 8,3$. The sizes of the amplification products were estimated by comparison with a 100-bp molecular size ladder (Thermo Scientific, Fermentas). Gels were stained with ethidium bromide (Sigma-Aldrich) and visualized using the system for the documentation of fluorescently stained gels G-BOX F3 (Syngene) and analyzed using the program Gene Tools (Syngene). Each profile was visually compared with those obtained from the reference strains: Listeria monocytogenes NCIMB 13726.

Table 1: Primers used for the amplification of the Listeria spp. and Listeria monocytogenes

\begin{tabular}{lllcl}
\hline Primer & \multicolumn{1}{c}{ Sequence $\left(5^{\prime}-3^{\prime}\right)$} & $\begin{array}{c}\text { Destination/target } \\
\text { gene }\end{array}$ & $\begin{array}{c}\text { Product } \\
\text { size }\end{array}$ & References \\
\hline U1 & CAG CMG CCG CGG TAA TWC & Listeria spp & 938 bp & Szymczak \\
LI1 & CTC CAT AAA GGT GAC CCT & & et al. 2011 \\
Iap1 & CGA ATC TAA CGG CTG GCA CA & L. monocytogenes & 287 bp & \\
Iap2 & GCC CAA ATA GTG TCA CCG CT & T. &
\end{tabular}

Source: Authors

Detection of biofilm formation by the microplate (MP) method

The method for assessment of biofilm formation by the MP method was based on the techniques proposed previously by Stepanovic et al. (2004) with some modifications described previously (Chajęcka-Wierzchowska, Zadernowska \& Łaniewska-Trokenheim, 2016). Wells of a sterile 96-well flat-bottomed sterile polystyrene microtiter plates were filled with $200 \mu \mathrm{l}$ of fresh sterile broth BHI (Merck, Poland). An overnight cultures $(20 \mu \mathrm{l})$ of each strain with a cell density of $1 \times 10^{9}$ cells $/ \mathrm{ml}$ were added in triplicate, onto the 96-well plates. Negative control wells contained broth only. The plates were covered and incubated aerobically at $36^{\circ} \mathrm{C}$ for 24 hours. The bacterial suspension was aspirated and each well was washed three times with $250 \mu \mathrm{L}$ of PBS buffer (Sigma). After that, the biofilm was fixed with $200 \mu \mathrm{L}$ of ethanol (99\%) for 15 minutes, and later removed. The plates were dried at room temperature, stained with $200 \mu \mathrm{L}$ of crystal violet solution used for Gram staining (Merck, Germany) for 5 minutes, washed in running water until the unbound crystal violet was removed and dried at room temperature. The dye bound to the adherent cells was re-solubilized with $160 \mu \mathrm{L}$ of $33 \%$ (v/v) glacial acetic acid (Sigma) per well. Absorbance was read using an Infinite M1000 PRO plate reader (Tecan) at $570 \mathrm{~nm}$. The optical density (ODs) of each strain was obtained by the arithmetic mean of the absorbance of three wells and this value was compared with the cut-off $\mathrm{OD}\left(\mathrm{OD}_{\mathrm{c}}\right)$ which was defined as three standard deviations above the mean OD of the negative control. The following classification was used for the determination of biofilm formation: no biofilm production $(\mathrm{OD} \leq \mathrm{ODc})$, weak biofilm production $(\mathrm{ODc}<\mathrm{OD} \leq 2 \mathrm{xODc})$, moderate biofilm production $(2 \mathrm{xODc}<\mathrm{OD} \leq 4 \mathrm{xODc})$ and strong biofilm production $(4 \times \mathrm{ODc}<\mathrm{OD})$. 


\section{Results and discussion}

A total of 130 meat samples, including poultry, beef and pork meat were analysed for Listeria monocytogenes. Results are summarized in Table 2 . The prevalence of L. monocytogenes in raw meats marketed in Olsztyn (Poland) was 17\%. The percent occurrence of Listeria monocytogenes in the tested meat in descending order was poultry (20\%), beef $(9,8 \%)$ and pork (4,5\%). Capita et al. (2001) isolated Listeria monocytogenes from $15 \%$ of poultry carcasses. A study conducted by Vitas (2004) in Navarra (Spain) revealed the presence of Listeria monocytogenes in 34.9\% in minced pork and beef and 36.1\% in poultry meat. No documented outbreaks of listeriosis have yet been directly attributed to the consumption of poultry meat. Nevertheless, the high prevalence of L. monocytogenes in poultry meat presents a potential risk, which may lead to outbreaks of listeriosis (Capita et al. 2001).

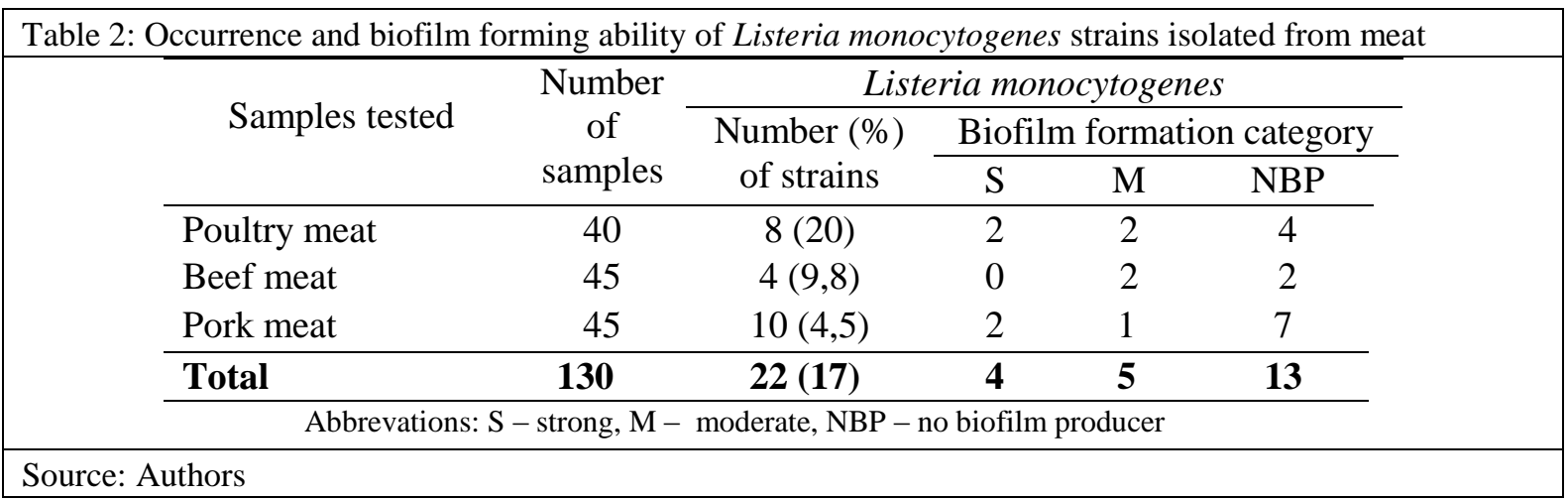

The pathogens' ability to form biofilms has a twofold meaning. From a medical point of view, the ability to form it is a feature which proves the strain's virulence. Components of a biofilm matrix protect bacteria against an immune attack and against penetration of chemotherapeutics. However, in terms of their industrial significance, strains which can form biofilms of manufacturing surfaces can pose a big problem; they are more difficult to remove from those surfaces, they can be less sensitive to disinfectants and they often cause secondary (cross) infections in the food industry (Shi \& Zhu X 2009, Zadernowska, Chajęcka-Wierzchowska \& Łaniewska-Trokenheim 2017). Strains of L. monocytogenes are recurrently found on surfaces in the food industry, notably in refrigerated premises, even though these are routinely cleaned and disinfected (Carpentier et al. 2004). The majority of the Listeria monocytogenes strains were characterized by a no biofilm producer $(n=13)$, or moderate ability to form a biofilm $(n=5)$, only four of the investigate strains showed a strong ability to produce biofilm (Table 2). In a study conducted by Barbosa et al. (2013) revealed that most food isolates were classified as weak or moderate biofilm formers, although the majority were weak. In a study conducted by Kalmkoff et al. (2001), significant differences were found in the ability of various L. monocytogenes strains to attach to a test surface. In monoculture, the majority of strains did not form biofilms which coincides with our results.

\section{Conclusions}

Our results and data presented by other authors demonstrate the ubiquitous occurrence of $L$. monocytogenes in raw chicken, beef and pork meat. Since L. monocytogenes may be present in meat the consumption of raw or undercooked meat can be an important factor in the transmission and epidemiology of Listeria monocytogenes infection. It is also necessary to raise consumer awareness regarding secondary infections, which can occur during the transport of meat from a shop or during its processing. Regular monitoring of Listeria monocytogenes prevalence in food are necessary for disease surveillance and tracing the epidemic outbreaks.

\section{References}

Bailey J., Fletcher D., Cox N., (1989). Recovery and serotype distribution of Listeria monocytogenes from broiler chickens in the southeastern United States. The Lancet. 1, 148-150

Barbosa J., Borges S., Camilo R., Magalhães R., Ferreira V., Santos I., Silva J., Gonçalo A., Teixeira, P. (2013). Biofilm Formation among Clinical and Food Isolates of Listeria monocytogenes. International Journal of Microbiology, Article ID 524975, 6 pages

Capita R., Alonso-Calleja C., Moreno B., García-Fernández M.C. (2001). Occurrence of Listeria species in retail poultry meat and comparison of a cultural/immunoassay for their detection. International Journal of Food Microbiology. 65(1), 75-82. 
Carpentier B., Cerf O. (2011) Review-Persistence of Listeria monocytogenes in food industry equipment and premises. International Journal of Food Microbiology. 145(1), 1-8.

Chajęcka-Wierzchowska W., Zadernowska A. \& Łaniewska-Trokenheim Ł. (2016). Virulence factors, antimicrobial resistance and biofilm formation in Enterococcus spp. isolated from retail shrimps. LWT - Food Science and Technology. 69, 117-122. Elliot T. Ryser Elmer H. Marth Listeria, Listeriosis, and Food Safety. (2007). Third Edition by CRC Press

Fux C. A., Costerton J. W., Stewart P. S., Stoodley P. (2005). Survival strategies of infectious biofilms. Trends in microbiology, 13(1), 34-40.

Kalmokoff M.L., Austin J.W., Wan X.-D., Sanders G., Banerjee S., Farber J.M. (2001). Adsorption, attachment and biofilm formation among isolates of Listeria monocytogenes using model conditions. Journal of Applied Microbiology. 91: 725-734.

Kramarenko T., Roasto M., Meremae K., Kuningas M., Poltsama P., Elias T. (2013). Listeria monocytogenes prevalence and serotype diversity in various foods. Food Control. 30:24-9.

Mafu A.A., Roy D., Goulet, J., Magny P., (1990). Attachment of Listeria monocytogenes to stainless steel, glass, polypropylene, and rubber surfaces after short contact times. Journal of Food Protection. 53, 742-246.

Stepanović S., Ćirković I., Ranin L. Svabić-Vlahović, M. (2004). Biofilm formation by Salmonella spp. and Listeria monocytogenes on plastic surface. Letters in Applied Microbiology. 38, 428-432.

Szymczak B., Sawicki W., Bogusławska-Wąs E., Koronkiewicz A., Dąbrowski W. (2011). Występowanie L. monocytogenes w świeżych owocach i warzywach pochodzących z upraw ekologicznych województwa zachodniopomorskiego. Żywność Nauka Technologia Jakość. 2 (75), 67 - 76

Vitas A. I. (2004). Occurrence of Listeria monocytogenes in fresh and processed foods in Navarra (Spain). International Journal of Food Microbiology. 90(3), 349-356.

Zadernowska A., Chajęcka-Wierzchowska W. (2017). Prevalence, biofilm formation and virulence markers of Salmonella sp. and Yersinia enterocolitica in food of animal origin in Poland, LWT - Food Science and Technology, 75(2017), 552-556. 